\title{
SOME PRELIMINARY CONSIDERATIONS FOR THE LEGAL-ECONOMIC ANALYSIS OF CORPORATE SOCIAL RESPONSIBILITY
}

REFLEXIONES PRELIMINARES PARA EL ANÁLISIS IUS-ECONÓMICO DE LA RESPONSABILIDAD SOCIAL DE LAS EMPRESAS

\author{
Rubén Méndez Reátegui \\ Edison Tabra Ochoa**
}

\begin{abstract}
This review article presents some preliminary considerations and describes the evolution of corporate social responsibility, which is necessary for an informed study of this "tool". In that sense, the authors resort to a preliminary exploration of the conceptual framework of the legal-economic approach presenting social responsibility and the relationship that subsists
\end{abstract}

\footnotetext{
* Professor at the Pontificia Universidad Católica del Ecuador (PUCE) and Visiting Professor at the Universidad Tecnológica del Perú. Visiting International Professor at Universidad Autónoma de Chile (this article was written in collaboration with this University during a research stay on the line "State Reform"). Visiting International Professor at Universidad Externado de Colombia. Ph.D. (c) at the University of Salamanca (Spain). Participant at the "Programa de Postdoctorado América Latina en el Orden Global" at Colegio de América, Universidad Andina Simón Bolívar (Ecuador). Ph.D. in Economics from Macquarie University (Australia). D.Sc. in CC.SS. and Economics from University Rey Juan Carlos (Spain). This article is presented in fulfillment of research activities of the Pontificia Universidad Católica del Ecuador for semester 2021-II, Grupo de Investigación en Derecho Económico of the Pontificia Universidad Católica del Ecuador (GIDE-PUCE). https://orcid.org/0000-0001-8702-5021.rcmendez@ puce.edu.ec

** Professor at the Pontificia Universidad Católica del Perú. International Doctorate and Master's Degree in Government and Culture of Organizations from the University of Navarra (Spain). Master in Business Law from the Pontificia Universidad Católica del Perú. Lawyer. His career includes work in corporate matters, mainly in Commercial Law, Corporate Governance and Social Responsibility. Member of the Commission in charge of revising the Peruvian General Corporations Law. https://orcid.org/0000-0002-6126-841X. etabra@pucp.edu.pe
} 
with "property rights", the relevance of "transaction costs", among other aspects. They also explore the interrelation between social responsibility and its forms of legal exercise and its characterization in areas that involve linking it with workers, unions, and consumers. The aim is to highlight its importance and build a contribution where social responsibility will be studied from an analytical and empirical perspective. Thus, it is sought to conclude that the company considers implementing and complying with good corporate governance standards since they expand the shared vision of business management, effectively allocating resources to obtain the most significant benefits of establishing a corporate social responsibility regime.

Keywords: Social Responsibility, Economic System, Institution, Agreements, Company

Resumen: Este artículo de revisión presenta algunas consideraciones preliminares y describe la evolución de la responsabilidad social de las empresas, necesaria para un estudio informado de esta "herramienta". En ese sentido, los autores recurren a una exploración preliminar del marco conceptual del enfoque jurídico-económico que presenta la responsabilidad social y la relación que subsiste con los "derechos de propiedad", la relevancia de los "costos de transacción”, entre otros aspectos. También se explora la interrelación entre la responsabilidad social y sus formas de ejercicio jurídico y su caracterización en ámbitos que implican su vinculación con los trabajadores, los sindicatos y los consumidores. El objetivo es destacar su importancia y construir un aporte donde la responsabilidad social sea estudiada desde una perspectiva analítica y empírica. Así, se busca concluir que la empresa considere la implementación y el cumplimiento de las normas de buen gobierno corporativo ya que amplían la visión compartida de la gestión empresarial, asignando efectivamente los recursos para obtener los beneficios más significativos del establecimiento de un régimen de responsabilidad social corporativa.

Palabras clave: Responsabilidad social, sistema económico, institución, acuerdos, empresa

Summary. I. Introduction. II. "Institutional Framework" and Social Responsibility: Some Links. III. Evolution of Social Responsibility. IV. Social Responsibility and Its Forms of "Legal Practice". V. Social Responsibility: Workers and Unions. VI. Social Responsibility: Consumers. VII. Social Responsibility: Suppliers. VIII. Social Responsibility: Public Administration. IX. Law and Practice of Corporate Social Responsibility. X. Conclusions. References. 


\section{INTRODUCTION}

Social responsibility is a concept that arose as a response to the company's actions or its representatives. In other words, the "responsible" and "social" criteria emerged as "incentive" mechanisms for companies to assume the external costs that the development of their economic activity could generate in society. Although it is considered that this purpose does not always coincide with the primary purpose of the companies because it detracts from their profit-making nature (in the specific case of the so-called profit organizations). It is argued that social responsibility represents a distortion of the economic nature of any business organization. This nature can be characterized by the pursuit of an eminently lucrative commercial activity. In contrast to the above, it is also expressed that social responsibility represents an opportunity and, therefore, companies would need to include and regulate its criteria. It is assumed based on the projection of the benefits that social responsibility would generate for the survival of companies in the market, which would far exceed the limitations caused by the costs of affecting freedom of enterprise and others on the part of governments.

Likewise, there is still an exciting and controversial discussion on the end that the practice of social responsibility should achieve. Two prominent positions stand out. The first is based on the contributions of Milton Friedman (1970) and postulates the investor as the basis for the exercise of responsible practices (stockholder theory). This implies characterizing the investor as the owner of the company, i.e., the agent entitled to receive the fruits or dividends generated by its commercial activity, as suggested by Macey (2014, p. 5). Concerning Corporate Social Responsibility, Macey (2014) argues that:

«The law \& economics of corporate social responsibility is simple. Assets are worth more to their owners if they are owned exclusively by those owners and not shared. This simple fact explains why shareholders prefer to be the exclusive beneficiaries of corporate fiduciary duties. However, if the "rules of the game" were changed and corporations were deemed to have responsibilities to society at large, rather than exclusively to their shareholders, shareholders would be harmed because the economic value of their shares would decline. Of course, shareholders would agree to a change such that corporations would owe their duties to society rather than to shareholders exclusively if they were compensated for this decrease in rights. Therefore, if non-shareholder groups, such as local communities, workers, suppliers, or customers, value these rights sufficiently, they would have them because they would buy them from shareholders. The fact that this does not happen is strong evidence that it is efficient to organize corporations so that they are run to maximize shareholder value» (p. 43). 
Based on this postulate, it would be said that the entire business organization must limit its actions to satisfy the economic expectations of those who made its existence as a company possible. This, to the extent that the investor contributed the necessary capital for the organization's constitution and the performance of its commercial activities that satisfy the market's expectations, is also its owner. However, it should be noted that this proposal, despite starts from postulates such as the defence of "property rights", understood as the ability to adapt or make decisions regarding goods or services, leaves aside alternative characterizations of the entrepreneur or homo agens in its different levels of analysis (Boettke, 2014, p. 14). It is essential to point out that property rights are imperfect insofar as freedom of disposition is never complete.

This position also argues that the practice of social responsibility is based on the need to meet the expectations and goals of their owners and investors (principals). Therefore, the implementation of their responsible policies and good practices is directed to that end and, following this assumption, companies prioritize the exercise of "responsible" and "social" activities or practices whose main objective is to increase their economic profitability and, therefore, that of the investor (Socoliuc et al., 2020, p. 4). This interpretation is based on the modelling of the entrepreneur as a neoclassical homo economicus. However, it leaves aside other proposals such as those introduced by heterodox schools such as the "Austrian" and, in a diffuse way, the neo-institutional. In this sense, the formulation of new scopes that allow considering alternative theoretical postulates is considered pertinent (San Emeterio, 2006, p. 10; Manne, 2011, p. 245; Méndez, 2017, p. 45). Likewise, the review of the contributions of neo-Keynesian economists such as William Baumol (1990, p. 5).

The antagonistic position, proposed by Freeman (2010) and considered by Fernández \& Bajo (2012, p. 23), outlines the stakeholder theory and argues that companies constitute an instrument for the satisfaction of all their stakeholders. In this order of ideas, it is established that business activity generates welfare for those who own the capital and those who contribute directly or indirectly to the practice of its commercial activity. It is based on the criterion that entrepreneurial activity satisfies the market's expectations but, at the same time, shares the consequences produced by the exercise of such activity. In other words, the exercise of social responsibility practices seeks to generate value for the company's stakeholders, which is economicfinancial and social (Rodríguez et al., 2020, p. 34).

Departing from the preceding, this review article proposes some preliminary considerations and reflections necessary for a legal-economic and conceptual analysis of corporate social responsibility. Therefore, it 
begins by establishing the links between social responsibility and the institutional framework. It continues with a characterization of the evolution of social responsibility, its forms of legal exercise, and its characterization in areas that involve linking it with workers, unions, and consumers (Peng Low, 2016, p. 3).

Then, based on a qualitative and descriptive methodological approach, such as the one proposed in this article, it can be argued that social responsibility generates value for the company. Therefore, there must be a positive influence on the part of the companies to implement their impact, mechanisms to avoid costly (negative) externalities, and control stakeholders. The methodological proposal implemented seeks to explain why business measures have generally been adapted to the existing legal barriers for developing their economic activities. However, the tools must be generated internally to propose an external impact that generates "reputation" and other important aspects.

Furthermore, seen in a technical sense, the bibliographic review constituted this research project's fundamental and central stage. It sought to guarantee to obtain the most relevant information to study preliminary considerations for the legal-economic analysis of corporate social responsibility.

Therefore, we worked to effectively discern from a universe of documents that can be very extensive in terms of their academic relevance. Therefore, the methodology proposed for the bibliographic review can be applied and replicated to any subject of legal research to determine its relevance and importance and ensure its originality. Together, it allows other researchers to consult the bibliographic sources cited, understanding, and perhaps continuing the work carried out. The proposed methodology consisted of three elements:

(i) Guiding axis established from the definition of the topic of discussion, that is, the legal-economic analysis of corporate social responsibility.

(ii) Search for legal-economic information from a structured perspective and considering as a decisive criterion that the material used can be classified as "recognized", "current" and "pertinent". "Proposals focused mainly on the dissemination of ideas" (advocacy) or texts "without scientific significance" (low impact on academia) were rejected. Therefore, it was verified that the works have been recognized and pose an innovative proposal.

(iii) Organization and analysis of the information involved in developing idea maps built from cross-cutting and joint concepts in the revised legal-economic information. Furthermore, this made it possible to 
relate the elements that justified the bibliographic selection based on their "levels of closeness" and impact on the mainline and mainstream literature whose axis of discussion was the legal-economic analysis of corporate social responsibility.

\section{II. "INSTITUTIONAL FRAMEWORK" AND SOCIAL RESPONSIBILITY: SOME LINKS}

Identifying the determinants of economic performance is one of the most relevant topics for economic theory and represents one of the areas of most significant debate in the specialized literature (Méndez, 2017, p. 55). However, empirical evidence suggests that those countries possess the most solid, efficient, and effective institutional framework that achieves tremendous growth and development (Acemoglu \& Johnson, 2005, p. 42; Acemoglu, Johnson, \& Robinson, 2005, p. 21). However, what does institutional framework mean, and what is its relevance for law and social responsibility?

Although there is no univocal definition of the institutional framework, we can characterize it as the complex amalgam of rules of the game that, according to Hollingsworth (2000), is mainly composed of:

(i) Institutions such as norms, rules, conventions, values, lifestyles, among others.

(ii) Institutional sectors are understood as markets, states, corporate hierarchies, and organizations in their different characterizations (p. 35).

San Emeterio (2006) summarizes the following classification (consisting of four categories or axes):

(i) Economic institutions: focused on the allocation and distribution of resources and the functioning of markets.

(ii) Political institutions: which focus on the design of the election system, electoral rules, political institutions, composition of government and opposition parties, and political checks and balances.

(iii) Legal institutions: are those that must deal with the type of legal system and the definition and enforcement of property rights.

(iv) Social institutions: related to access rights, such as health benefits, education, and social security arrangements (p. 55).

Within this amalgam of rules of the game is social responsibility, expressed through private and public rules. Since their inclusion within the institutional framework contributes to shaping property rights that provide markets with an environment of low transaction costs where economic competition can exist and flourish. Based on the application of the Coase 
theorem, it can be stated that one of the main obstacles to efficient economic performance lies in the presence of "high" transaction costs, in other words, the cost of carrying out economic transactions or using the market (Fortes \& De Souza, 2020). Institutions will then be constituted as mechanisms that allow the management of these costs.

Moreover, without the existence of social responsibility rules that positively impact the institutional framework of property rights, individuals will see new external costs (real negative externalities) generated from investing in human or physical capital, developing, or adopting new technologies, or implementing new ideas. Therefore, good rules such as those derived from effective, efficient, and effective social responsibility practices will also improve the allocation of resources by better determining who receives the benefits, revenues, and control rights (subjective rights for decision making); or the burdens of individual and collective actions derived from in a cooperative scenario (exchange of property rights). An example of the inefficient practice of corporate social responsibility is constituted by greenwashing or deceptive practice, through which consumers who want environmentally "responsible" goods and services are "satisfied". In general, these practices transcend due to the institutional weakness in the countries and directly affect aspects such as legal enforcement. See the contribution by Miriam Cherry (2014, pp. 1-45) entitled "The Law and Economics of Corporate Social Responsibility and Greenwashing”.

On the contrary, the absence of social responsibility rules due to their "capture" or "blocking" by private agents (lobbies) or the State may (in the long run) affect the flourishing of markets. This represents a diseconomy that will negatively impact societies (Hollingsworth \& Boyer, 1997, p. 31) to promote innovation through the market process. Their economic and social agents manage to prosper in an environment of voluntary cooperation, nonaggression, and self-regulation. Good rules promote economic growth, and those that do not work impede it by perversely inducing economic agents (individuals, families, and firms) to engage in behaviors that hinder growth and efficient redistribution of income.

In conclusion, efficient and effective social responsibility rules should be included within the institutional framework and are essential because they help solve a critical economic problem of the agents: the coordination of their "business" plans and the development of specific productive activities through an efficient economic calculation (Zakharkin et al., 2019, p. 2). 


\section{EVOLUTION OF SOCIAL RESPONSIBILITY}

The exercise and elements of social responsibility are in a permanent stage of change. The traditional exercise that involved creating and implementing responsible and social practices that include criteria of economic, legal, ethical, and philanthropic responsibility has evolved to another, where responsibilities include those required to meet the local expectations of society (Masoud, 2017).

That is to say; social responsibility is no longer only translated into the company's business practices. However, it justifies its realization to consider those facts that happen around it and close to it, which implies a process of internationalization of "externalities". This involves a scenario where the costs of establishing, transferring, or maintaining property rights must be faced, which appear when these (subjective rights) are affected and imply, per se, the effective loss of a certain degree of freedom in their disposition.

Thus, the current trend in social responsibility involves attending to stakeholder's interests, whether they are close to those who manage the organizations, and which are assumed as a form of conduct or work.

Likewise, the importance of social responsibility today has generated the need to implement permanent mechanisms of social practices by companies (Ashrafi et al., 2018). However, this trend is coupled with the growing propensity of countries to intervene in its promotion through regulation (hard law) following their social policy programs.

In this sense, states tend to legislate social responsibility as part of the exercise of their political programs aimed at generating and providing welfare to the society of a country or nation (Acevedo et al., 2013, p. 12). In other words, a process of "juridification" of successful experiences of social responsibility created and implemented in the business sector is occurring more frequently. The practice of restricting and, subsequently, banning plastics in Spain is cited as a successful case (Schreuer, 2018, p. 41). In Spain, department store companies adopted this measure as part of their environmental care policies. Recently, this practice has been "normativized" by the government for mandatory compliance by all citizens.

Based on the changes in social responsibility trends, this can be defined as the set of business practices made in favour of society or the company itself to ensure their welfare. In other words, we are facing a concept that is no longer exclusive to companies, and, over time, its importance has led to its inclusion in the legislation of countries to require the rest of the members of society to practice it (Frederiksen, 2019, p. 65). 
Additionally, its use has been extended to the rest of the social groups, including the public administration.

Therefore, its interdisciplinary definition and the criteria that compose it require a legal protection mechanism and a guaranteeing legal scenario for its practice. Law plays an essential role in the promotion and exercise of social responsibility in favour of the members of society. This undoubtedly represents a new paradigm compared to any approach that may focus on the ethical component. This is so since the juridical-legal takes on a new protagonism in society since it represents an instrument that, due to its sizeable omnes character, can contribute to the massification of its practices and the protection of those carried out in the private sphere.

\section{SOCIAL RESPONSIBILITY AND ITS FORMS OF "LEGAL PRACTICE"}

The exercise of social responsibility is based on the generation of economic and social welfare for those who created an organization and hired the services of its collaborators (investors). Nevertheless, simultaneously, in the concern to include those stakeholders who have collaborated in generating their welfare directly or indirectly. In general, it has become a criterion that is gradually being extended to other members of society. Initially, it was incorporated by the business sector as an instrument that guarantees its permanence in the market and the sustainability of its commercial activity in the long term.

Currently, this term is present in the various interest groups (stakeholders) found in society. Therefore, it is not exceptional to find social responsibility in government, trade unions, suppliers, and other members of civil society, in addition to the recurrent use of terms such as responsible or supportive consumer or responsible consumption. It has also been extended to groups that, traditionally, were not considered in the economic activity of a company or, if they were, they played an indirect or secondary role. This includes subcontractors or suppliers of suppliers. Although they have no direct relationship with the company, these market players have come under the discipline of social responsibility because of their growing importance (Sanclemente-Téllez, 2017, p. 31). 


\section{SOCIAL RESPONSIBILITY: WORKERS AND UNIONS}

The practice of social responsibility has focused the company's development on its collaborators and workers. The basis of this assumption lies in the fact that companies need their contribution to achieve their business activity. This is so because the social and responsible practices implemented in business organizations aim to value employee's contribution and maintain their motivation to prevent their productivity from declining. In addition, a series of programs are usually carried out to promote the work environment, labour welfare, or retention of human talent. The latter to prevent high labour turnover.

However, the discussion on social responsibility actions that the collaborator and worker (employee) should perform for the company is a broad debate. In this regard, we believe that the employee's social responsibility rests on the correct performance of their work following the provisions of their employment contract, which derives from the search to find balances in agency scenarios (Mackenzie et al., 2014). In addition, the responsible and social practice of the employee must rest on the promotion and consistent compliance with the principles and values that characterize their workplace and help them be immune to problems such as corruption or non-compliance in the exercise of their duties.

Trade unions are traditionally presented as the exclusive protector of employee's interests. However, according to a conception of social responsibility, unions should be constituted as entities that collaborate in generating profits that benefit employees and the rest of the company's stakeholders. Unions should be constituted as entities that look after both the interests of the company and those of the investors or principals who hold its shares. This is so since a harmonious duality between agents and principals makes it possible to establish essential synergies for the correct performance of the economic units (companies) and minimize risks such as free rider behavior, moral hazard, and natural negative externalities others (Morseletto, 2020, p. 9). The above coincide with the interests of the worker and his search for protection and external protection to establish a proper balance between his rights, legal rules, and the property rights of the owners or agents who act as principal delegates of the organizations. 


\section{SOCIAL RESPONSIBILITY: CONSUMERS}

As in the case of employees, the notion of social responsibility on consumers is a developing field (Tabra, 2017; Arredondo et al., 2011, p. 9). There remains the belief that social responsibility is the exclusive patrimony of companies and their stakeholders. This point requires better precision since consumers have acquired power and influence in the choice of products offered by the market. In this sense, social networks are the means of communication par excellence of and among consumers, as explained by Martínez et al. (2019, p. 36).

So-called "consumer power" therefore has a significant influence on the market. However, it should not be exercised in an uncontrolled or absolute manner. Let us remember that the game described above involves maintaining the balance between agents and principals, which reduces real negative externalities and, therefore, maximizes the interest of stockholders and stakeholders.

In a practical sense, achieving balance involves consumers giving their opinions on product quality in a timely, relevant, and proactive manner, favouring them and limiting scenarios where opinions on goods and services are unfair and unfounded. For this reason, we believe that the social responsibility of consumers should be reflected in the self-limitation of their power and the consequent influence they exert on the market. Thus, their opinions, criticisms, or complaints about market offers (companies) must meet a standard of justification and reasonableness that prevents the commission of any abuse of their consumer rights.

Similarly, the dual prevention of external effects (understood as legal injustices, infringement of rights, and others) should lead consumer associations to implement a criterion of attention and defence of the rights of their members restricted to prevent any abuse or harm to the interests of companies (Friedland, 2021, p. 6). However, the associations should promote compliance with consumer obligations. These measures can help balance the protection of the rights that all consumers have but simultaneously make sure that they comply with their obligations, protect their rights, and protect the interests of other interest's groups.

\section{SOCIAL RESPONSIBILITY: SUPPLIERS}

The notion of supplier social responsibility proposes a degree of the obligation of the supplier towards the company. It implies that the supplier 
does not limit its commitment only to comply with the contract's provisions. The supplier can also exercise social responsibility on several fronts, which can be summarized as follows:

(i) The promotion of the importance of responsible and social practices to those organizations and individuals who are not involved with the leading company. In this case, the supplier can extend its practice to subcontractors. It should be considered that the criteria of corporate reputation and sustainability are at risk and, therefore, it is essential that suppliers do not commit any act that affects it.

(ii) The extension of values linked to the company's organizational culture. Companies, mainly transnationals, incorporate corporate values and principles that distinguish them from other organizations. Moreover, they seek to expand as part of their process of installation and operation in the market. Many of these principles are linked to protecting society's interests (environment, human rights, and governance). Because of the above, suppliers are an essential element in the transmission of these ethical elements.

(iii) Self-regulation rather than administrative impositions by the public administration. This implies the prevalence of social and responsible practices on the part of supplier companies.

\section{SOCIAL RESPONSIBILITY: PUBLIC ADMINISTRATION}

The ideal way for public administration to practice social responsibility is limited to compliance with regulations. Unlike private companies, state institutions limit their activities to comply with the rules of their sector. In this sense, social responsibility in the government sector should be developed inadequate compliance with its operating rules. Likewise, it is also necessary to effectively supervise its official's conduct to prevent any case of fraud.

Finally, another issue that deserves to be included is the correct creation, modification, and suppression of legal norms in regulating market agents or society. In this sense, the State must have efficient political institutions that allow it to create laws that meet the expectations of individuals and companies. Therefore, efficient state social responsibility means creating law efficiently and following society's expectations (Lindman et al., 2020, p. 14). This scenario coincides with the principalagent model mentioned above, in which the citizenry assumes the role of principal, i.e., holder of rights, in this case, inalienable rights. 


\section{LAW AND PRACTICE OF CORPORATE SOCIAL RESPONSIBILITY}

The law has granted an almost residual function to social responsibility. It has been confined to configuring a "permitted" space for the exercise of responsible practices. On the contrary, contributions from ethics and economics have taken a leading role in elaborating policies or practices. Thus, it has often been observed that forms of responsible and social practice have been elaborated based on economic measurements or as part of a business organization's corporate culture of integrity.

In this context, we think that the law must also play an essential role in promoting social responsibility. This becomes even more relevant if we overcome a first error that consists in believing that law is circumscribed solely and necessarily to the "coercive" element of the State. That is, the idea that the State must back a rule to ensure compliance. Nevertheless, we cannot take this view as unquestionable. The transcendence of material legitimacy and a broad understanding of the sources of law in a context of institutional coordination should leave ample room for social initiative (Méndez, 2017, p. 79).

If law, above all, is understood as the creation of norms or rules of conduct that society requires to live in harmony and justice, why not extend this idea to the field of self-regulation used in the creation of social responsibility practices? While state regulation needs the support of the state to enforce its rules, self-regulation creates its own rules that have the support and authority of the one who created them (the entrepreneur).

In this sense, if we assume that a large part of the practice of social responsibility rests on self-regulation, we must understand that compliance depends on who develops them and enforces them. The creation of a company's own rules is due to the organizational culture of the entrepreneur. As the organization owner, the entrepreneur uses self-regulation to create his own rules to ensure the proper behavior of the members of the organization and efficient commercial performance in the market. This is the reason for compliance with self-regulation rules: the need to ensure the company's proper functioning and, thus, to ensure the entrepreneur's well-being.

Corporate social responsibility bases its practice on creating and complying with its own rules to guarantee the sustainability of its activity and its long-term permanence in the market (Noti et al., 2020, p. 7). We believe that this is where the effectiveness of these standards lies, whereas, in the case of state standards, the existence of the state's coercive apparatus is needed to force or verify compliance with its rules. However, we assume the criterion that regulatory and self-regulatory norms should not be 
differentiated only by their coercive nature but by the effectiveness of their compliance. Furthermore, at this point, self-regulatory norms acquire greater effectiveness: they guarantee the company's purposes and those expressed in the regulatory norms.

Soft law standards are worth mentioning. These are recommendations issued by national or international organizations, such as the OECD, in social responsibility to include them in their social responsibility practices. In South America, these standards have been aimed mainly at publicly traded companies to improve their corporate reputation in the market. At present, reputation has become a priority for corporations because it is a determining factor in the sustainability of the business activity. Especially if we observe that reputation has gone from being evaluated in the internal sphere of the company to the public sphere (society).

Society has become the protagonist of corporate business sustainability. Thus, the use of social networks has generated a trend towards consumer "activism". This activism translates into a permanent citizen "scrutiny" of the products offered by the company and the quality of service it provides to the market. It also evaluates how the organization treats its employees and other stakeholders. Nevertheless, this must be added as the extension of the risk for those companies or entities that carry out some activity in connection with it. This is the case of supplier companies, identified as part of the leading company, and can damage its image.

Thus, for example, we can highlight the case of activities carried out by contractors of a mining company that do not respect the labour rights of their employees. Citizens do not distinguish the differences in legal status or the links and management differences between them; they tend to identify them as part of the leading company and the consequent institutional discredit. For this reason, social responsibility has become an instrument for safeguarding the corporate reputation of the company and those linked to it.

In these cases, self-regulation is of the utmost interest to safeguard the company's image. We believe that its exercise corresponds to its administrator, who must implement social responsibility policies as part of his fiduciary obligations (care and loyalty) with the company and ensure that the guarantor mechanisms are implemented to ensure compliance.

The rules of meta regulation constitute another form of exercise of the law. These are norms that promote conduct or the performance of legally relevant acts but do not require state coercion. Unlike regulatory norms, which oblige or prohibit the commission of an act, in the case of meta regulation, there is no sanction for non-compliance. Likewise, metal regulatory norms are rules based on promoting the performance of behaviors or prohibiting them in exchange for some type of economic benefit 
(Akkalathama, 2021). They are created by the states, which use them to encourage certain types of conduct.

On the other hand, it has come to be perceived that, through their metaregulatory norms, companies can enforce these fundamental rights in those partner companies with which they maintain commercial relations. Thus, for example, there are anti-corruption clauses that strongly discourage a company's suppliers from committing acts of fraud: fraud, bribery, money laundering, or other acts classified as corruption are contractually penalized to the economic detriment of the guilty party. Labour protection clauses have also been developed, which allow a company to terminate its contract with its suppliers without any consideration if they violate the rights of its workers.

Likewise, the promotion of and compliance with ethical or integrity codes containing the behaviors that their members must follow and indicating the sanctions in case of non-compliance are also sought. An example of this is the regulations of the stock market authorities, which encourage the use of codes of good governance by companies wishing to be listed on the stock exchange.

\section{Conclusions}

1. This review article focused on characterizing social responsibility from a theoretical-conceptual approach where the legal-economic perspective assumes a leading role. The exercise involved multiple reflections linking social responsibility with property rights or consideration of aspects such as transaction costs. This implied inserting the study of social responsibility within an evolution as a tool and establishing specific links with the forms of legal exercise of social responsibility and its characterization in specific areas that also implied linking it with workers, trade unions, and consumers.

2. Likewise, in social responsibility, this article argued that met regulatory standards had become an essential promotional tool used by governments to promote responsible practices following their goals and objectives. These goals focus on environmental issues, human rights, and governance. It should be recalled that concerning the environment, states encourage companies to become involved in the care of the environment and to assume the costs of pollution generated by their business activities.

3. In addition, the characterization developed through this article established that met regulatory standards are intended to engage business organizations in respecting the human rights of their stakeholders. Due to 
the scope of their activities, the interests of their workers, suppliers, and consumers, who are the groups most likely to have their rights violated by business decisions.

4. Finally, the idea that meta regulation standards also promote corporate governance was defended. In other words, the aim is for the company to create, implement and comply with good corporate governance standards that enable it to manage its material and human resources adequately.

\section{REFERENCES}

Acemoglu, D., \& Johnson, S. (2005). Unbundling Institutions. Journal of Political Economy, 113 (5), 949-995.

Acemoglu, D., Johnson, S., \& Robinson, J. A. (2005). Chapter 6 - Institutions as a Fundamental Cause of Long-Run Growth. In Aghion, P., \& Durlauf, S. N. (Eds.), Handbook of Economic Growth, 1, Part A, 385-472. North Holland.

Acevedo, J. A., Zárate, R., \& Garzón, W. F. (2013). Legal Status of Corporate Social Responsibility (CSR) in Colombia. Díkaion, 22 (2), 303-332.

Akkalathama, W., \& Taghipour, A. (2021). Pro-Environmental Behavior Model Creating Circular Economy in Steel Recycling Market, Empirical Study in Thailand. Environmental Challenges, 4, 100-112. DOI: 10.1016/j.envc.2021.100112

Arredondo Trapero, F. G., Maldonado de Lozada, V., \& De la Garza García, J. (2011). El consumidor ante la responsabilidad social corporativa. Actitudes según edad y género. Cuadernos de Administración, 24 (43), 285-305.

Ashrafi, M., Adams, M., Walker, T., \& Magnan, G. (2018). How Corporate Social Responsibility Can Be Integrated into Corporate Sustainability: A Theoretical Review of Their Relationships. The International Journal of Sustainable Development \& World Ecology, 25 (8), 671-681. DOI: 10.1080/13504509.2018.1471628

Baumol, W. J. (1990). Entrepreneurship: Productive, Unproductive, and Destructive. Journal of Political Economy, 98 (5), 893-921.

Boettke, P. J. (2014). Entrepreneurship and the Entrepreneurial Market Process: Israel M. Kirzner and the Two Levels of Analysis in Spontaneous Order Studies. Review Austrian Economics, 27. DOI: https://doi.org/10.1007/s11138-014-0252-1

Cherry, M. A. (2014). The Law and Economics of Corporate Social Responsibility and Greenwashing. U. C. Davis Business Law Journal, 282, Paper No. 2014-22.

Fernández, J. L., \& Bajo, A. (2012). La Teoría del Stakeholder o de los Grupos de Interés, pieza clave de la RSE, del éxito empresarial y de la sostenibilidad. aDResearch: Revista Internacional de Investigación en Comunicación, 6 (6), 130-143. DOI: 10.7263/adresic-006-02 
Fortes, B., \& De Souza, J. (2020). Decision of the Firm's Vertical Boundaries: Considerations on Complementarity. Contextus-Revista Contemporânea de Economia e Gestão, 18, 123-145.

Frederiksen, T. (2019). Political Settlements, the Mining Industry and Corporate Social Responsibility in Developing Countries. The Extractive Industries and Society, 6, (1), 162-170. DOI: https://doi.org/10.1016/j.exis.2018.07.007

Freeman, R. E. (2010). Strategic Management: A Stakeholder Approach. Cambridge University Press. DOI: https://doi.org/10.1017/CBO978113919267

Friedland, B., Mathur, S., \& Haddad, L. (2021). The Promise of the Dual Prevention Pill: A Framework for Development and Introduction. Frontiers. DOI: https://doi.org/10.3389/frph.2021.682689

Friedman, M. (13-IX-1970). The Social Responsibility of a Business Is to Increase Profits. The New York Times Magazine.

Hollingsworth, J. R. (2000). Doing Institutional Analysis: Implications for the Study of Innovations. Review of International Political Economy, 7 (4), 595-644. DOI: https://doi.org/10.1080/096922900750034563

Hollingsworth, J. R., \& Boyer, R. (1997). Coordination of Economic Actors and Social Systems of Production. In Hollingsworth, J. R., \& Boyer, R. (Eds.), Contemporary Capitalism: The Embeddedness of Institutions, 1-48. Cambridge University Press. DOI: https://doi.org/10.1017/CBO9781139174701.001

Lindman, A., Ranängen, H., \& Kauppila, O. (2020). Guiding Corporate Social Responsibility Practice for Social License to Operate: A Nordic Mining Perspective. The Extractive Industries and Society, 7 (3), 892-907. DOI: https://doi.org/10.1016/j.exis.2020.07.013

Macey, J. R. (2014). Corporate Social Responsibility: A Law \& Economics Perspective. Chapman Law Review, 17 (2), 331-354.

Mackenzie Torres, T., Buitrago Quintero, M. T., Giraldo Vélez, P., \& Parra Sánchez, J. H. (2014). Factores que explican la relación principal-agente en seis empresas de la ciudad de Manizales. Equidad \& Desarrollo, 22, 137-163. DOI: 10.19052/ed.3254

Manne, H. (2011). Entrepreneurship, Compensation, and the Corporation. The Quarterly Journal of Austrian Economics, 14 (1), 3-24.

Martínez-Rolán, X., Tymoshchuka, O., Piñero-Otero, T., \& Renó, D. (2019). Instagram as a Network of Promotion and Hypermediation of Rural Tourism: The Case of Aldeias Históricas. Revista Latina de Comunicación Social, 74, 1610-1632. DOI: 10.4185/RLCS-2019-1401en

Masoud, N. (2017). How to Win the Battle of Ideas in Corporate Social Responsibility: The International Pyramid Model of CSR. International Journal of Corporate Social Responsibility, 2 (4), 1-22.

Méndez, R. (2017). Essays on Institutions, Coordination and Legal Theory. Centro de Publicaciones PUCE. 
Morseletto, P. (2020). Targets for a Circular Economy. Resources, Conservation and Recycling, 153, 104-553. DOI: https://doi.org/10.1016/j.resconrec.2019.104553

Noti, K., Mucciarelli, F., Angelici, C., Pozza, V., \& Pillinini, M. (2020). Corporate Social Responsibility (CSR) and Its Implementation into EU Company Law. Policy Department for Citizen's Rights and Constitutional Affairs.

Peng Low, M. (2016). Corporate Social Responsibility and the Evolution of Internal Corporate Social Responsibility in $21^{\text {st }}$ Century. Asian Journal of Social Sciences and Management Studies, 3 (1), 56-74. DOI:

10.20448/journal.500/2016.3.1/500.1.56.74

Rodríguez, S., Arco-Castro, M., López-Pérez, M., \& Rodríguez-Ariza, L. (2020). Where Does CSR Come from and Where Does It Go? A Review of the State of the Art. Administrative Science, 10 (60), 1-19. DOI: 10.3390/admsci10030060

Sanclemente-Téllez, J. (2017). Marketing and Corporate Social Responsibility (CSR). Moving Between Broadening the Concept of Marketing and Social Factors as a Marketing Strategy. Spanish Journal of Marketing, 21 (1), 4-25. DOI: https://doi.org/10.1016/j.sjme.2017.05.001

San Emeterio, M. (2006). New Institutional Economics. Síntesis.

Schreuer, M. (28-V-2018). Europe Proposes Banning Plastics from Cleaning Up Oceans. The New York Times. https://www.nytimes.com/es/2018/06/05/union-europeaprohibir-plasticos-playa/

Socoliuc, M., Cosmulese, C., Ciubotariu, M., Mihaila, S., Arion, I., \& Grosu, V. (2020). Sustainability Reporting as a Mixture of CSR and Sustainable Development. A Model for Micro-Enterprises within the Romanian Forestry Sector. Sustainability, 12 (603), 1-34. DOI: https://doi.org/10.3390/su12020603

Tabra, E. (2017). Responsabilidad social y gobierno corporativo. Fondo Editorial USIL.

Zakharkin, O., Basantsov, V., Myroshnychenko, O., \& Shcherbachenko, O. (2019). Analysis of the Innovative Development Directions for Industrial Enterprises. Revista Espacios, 40 (27), 16. 